UDC 539.3

DOI: http://dx.doi.org/10.20535/0203-377129201565604

S. I. Trubachov ${ }^{1}$, доцент, O. N. Alekseichuk ${ }^{2}$, доцент

\title{
BENDING OF COMPOSITE SHELLS BASED ON NON-LINEAR DISTRIBUTION OF DISPLACEMENTS ACROSS THE THICKNESS OF FILLER
}

Ua У роботі представлена методика розрахунку композитних шаруватих оболонок, яка заснована на варіаційно-сітковому підході формування необхідних функціоналів з подальшою мінімізацією їх методом покоординатного спуску, який є методом нелінійного програмування. Побудовані алгоритми чисельного розрахунку відрізняються стійкістю і економічністю з точки зору

\footnotetext{
${ }^{1}$ National Technical University of Ukraine "Kyiv Polytechnic Institute", Department of Dynamics and Strength of Machines and Strength of Materials

2 National Technical University of Ukraine "Kyiv Polytechnic Institute", Department of Theoretical Mechanics
} 
обчислювальних ресурсів. На прикладі чисельного експерименту була досліджена збіжність рішень.

Ru В работе представлена методика расчета композитных слоистых оболочек, которая основана на вариационно-сеточном подходе формирования необходимых функционалов с последующей минимизацией их методом покоординатного спуска, который является методом нелинейного программирования. Построенные алгоритмы численного расчета отличаются устойчивостью и экономичностью с точки зрения вычислительных ресурсов. На примере численного эксперимента была исследована сходимость решений.

\section{Introduction}

The problem of reliability of thin-walled structural elements brings to the fore the question of improving the accuracy of calculations. The fact is that the elements of the composite materials have a number of features, which are include the distinctly expressed anisotropic deformation properties, low resistance to transverse deformation and etc. Using the classical theory of shells is ignore these factors, in some cases, it leads to significant errors in the calculations. Therefore, a correct analysis of the problems of shell theory is requires the involvement of refined theory of higher order. In building a refined theory of approaches is basing on the adoption of the hypotheses for each layer separately, or a system of assumptions which were made for a package of layers in general.

\section{Formulation of the problem}

The layered shells that are made of high-strength composite materials with different stacking layers are widely used in aviation technology as elements of bearing aircraft surfaces as well as in many other industries. Thus, the perfection of calculations methods of the heterogeneous stratified constructions is an actual task. Along with the methods of non-destructive control, fault detections of constructions by means of vehicle methods, the numeral researches methods are very actual and allow forecasting the possible destruction of construction. Denotations are taken from the classic theory of shells [1]. kind:

Displacements of points in bearing layers of shell we'll present in a next

$$
\begin{gathered}
u^{(n)}\left(\alpha_{1}, \alpha_{2}, z\right)=u_{0}^{(n)}\left(\alpha_{1}, \alpha_{2}\right)+z^{(n)} \theta_{1}^{(n)}\left(\alpha_{1}, \alpha_{2}\right) \\
v^{(n)}\left(\alpha_{1}, \alpha_{2}, z\right)=v_{0}^{(n)}\left(\alpha_{1}, \alpha_{2}\right)+z^{(n)} \theta_{2}^{(n)}\left(\alpha_{1}, \alpha_{2}\right) \\
w^{(n)}\left(\alpha_{1}, \alpha_{2}, z\right)=w_{0}^{(n)}\left(\alpha_{1}, \alpha_{2}\right), \quad n=1,2,
\end{gathered}
$$

where $\theta_{1}^{(n)}$ and $\theta_{2}^{(n)}, n=1,2$ are the normal angles of rotation in the supporting layers in planes $\alpha_{1}=$ const, $\alpha_{2}=$ const: 


$$
\begin{aligned}
& \theta_{1}^{(n)}\left(\alpha_{1}, \alpha_{2}\right)=-\frac{1}{A_{1}} \frac{\partial w_{0}^{(n)}}{\partial \alpha_{1}}+\frac{u_{0}^{(n)}}{R_{1}}, \\
& \theta_{2}^{(n)}\left(\alpha_{1}, \alpha_{2}\right)=-\frac{1}{A_{2}} \frac{\partial w_{0}^{(n)}}{\partial \alpha_{2}}+\frac{v_{0}^{(n)}}{R_{2}}
\end{aligned}
$$

$u_{0}^{(n)}, v_{0}^{(n)}, w_{0}^{(n)}, n=1,2$ - are the components of point's displacements of the middle bearing surface layers in the direction of the coordinate axes in the accepted system of coordinates.

For a filler we are accept a nonlinear distribution of displacements

$$
\begin{gathered}
u^{(n)}\left(\alpha_{1}, \alpha_{2}, z\right)=u_{0}^{(n)}\left(\alpha_{1}, \alpha_{2}\right)+\sum_{m=1}^{3} u_{i}\left(\alpha_{1}, \alpha_{2}\right) z^{m} \\
v^{(n)}\left(\alpha_{1}, \alpha_{2}, z\right)=v_{0}^{(n)}\left(\alpha_{1}, \alpha_{2}\right)+\sum_{m=1}^{3} v_{i}\left(\alpha_{1}, \alpha_{2}\right) z^{m} \\
w^{(n)}\left(\alpha_{1}, \alpha_{2}, z\right)=w_{0}^{(n)}\left(\alpha_{1}, \alpha_{2}\right)+\sum_{m=1}^{3} w_{i}\left(\alpha_{1}, \alpha_{2}\right) z^{m}
\end{gathered}
$$

The stresses in the load-bearing layers can be represented as [1]

$$
\left\{\sigma^{(n)}\right\}=\left[G^{(n)}\right]\left\{\varepsilon^{(n)}\right\}, \quad n=1,2,
$$

where are $\left\{\sigma^{(n)}\right\}=\left\{\sigma_{1}^{(n)}, \sigma_{2}^{(n)}, \tau_{12}^{(n)}\right\}$ - the components of the stress tensor;

$\left\{\varepsilon^{(n)}\right\}=\left\{\varepsilon_{1}^{(n)}, \varepsilon_{2}^{(n)}, \gamma_{12}^{(n)}\right\}$ - are the components of the strain tensor;

$\left[G^{(n)}\right]=\left(\begin{array}{ccc}g_{11}^{(n)} & \mathrm{g}_{12}^{(\mathrm{n})} & g_{13}^{(n)} \\ \ldots & \mathrm{g}_{22}^{(\mathrm{n})} & g_{23}^{(n)} \\ \ldots & \ldots & g_{33}^{(n)}\end{array}\right)$ is the matrix elastic coefficients.

For an isotropic material bearing layers we have

$$
\begin{gathered}
g_{11}^{(n)}=g_{22}^{(n)}=\frac{E_{n}}{1-v_{2}^{(n)}}, \\
g_{12}^{(n)}=\frac{E_{n} v_{n}}{1-v_{n}^{2}}, \quad g_{33}^{(n)}=G^{(n)}, \\
g_{13}^{(n)}=g_{23}^{(n)}=0
\end{gathered}
$$

For the filler components as vectors $\left\{\sigma^{(3)}\right\}$ and $\left\{\varepsilon^{(3)}\right\}$ we are presented

$$
\begin{aligned}
& \left\{\sigma^{(3)}\right\}=\left\{\tau_{13}^{(3)}, \tau_{23}^{(3)}, \sigma_{3}^{(3)}\right\} \\
& \left\{\varepsilon^{(3)}\right\}=\left\{\gamma_{13}^{(3)}, \gamma_{23}^{(3)}, \varepsilon_{3}^{(3)}\right\}
\end{aligned}
$$

According to Hooke's law:

$$
\left\{\sigma^{(3)}\right\}=\left[G^{(3)}\right]\left\{\varepsilon^{(3)}\right\} .
$$


In the case of coincidence the axes of orthotropic with the coordinate lines the matrix $\left[G^{(3)}\right]$ has a diagonal structure:

$$
\left[G^{(3)}\right]=\left[g_{55}^{(3)}, g_{44}^{(3)}, g_{33}^{(3)}\right]
$$

where in for a homogeneous material thickness

$$
g_{55}^{(3)}=G_{13}^{(3)} ; \quad g_{44}^{(3)}=G_{23}^{(3)} ; \quad g_{33}^{(3)}=E_{z}^{(3)} .
$$

The potential energy of deformation of the sandwich plate is equal to the sum of the potential energy of deformation of bearing layers and the filler:

$$
u=\frac{1}{2} a(\mathrm{v}, \mathrm{v})=\frac{1}{2} \sum_{i=1}^{3} \int_{V(i)}\left\{\epsilon^{(i)}\right\}^{T}\left\{\sigma^{(i)}\right\} d V_{i},
$$

where are

$$
\begin{gathered}
\left\{\sigma^{(n)}\right\}=\left\{\sigma_{x}^{(n)}, \sigma_{y}^{(n)}, \tau_{x y}^{(n)}\right\} ;\left\{\epsilon^{(n)}\right\}=\left\{\epsilon_{x}^{(n)}, \epsilon_{y}^{(n)}, \gamma_{x y}^{(n)}\right\}, n=1,2 \\
\left\{\sigma^{(3)}\right\}=\left\{\tau_{x x}^{(3)}, \tau_{y x}^{(3)}, \sigma_{z}^{(3)}\right\} ;\left\{\epsilon^{(3)}\right\}=\left\{\gamma_{x z}^{(3)}, \gamma_{y z}^{(3)}, \epsilon_{z}^{(3)}\right\} .
\end{gathered}
$$

\section{Methods of solution}

To approximate the flexure of $n$-th thin carrier layer within each subregion we're using the function [2]

$$
\begin{aligned}
w_{0 h}^{(h)} & =w_{1}^{(n)} L_{1}+w_{2}^{(n)} L_{2}+w_{3}^{(n)} L_{3}+a_{1}^{(n)} L_{1}^{2} L_{2}+a_{2}^{(n)} L_{1}^{2} L_{3}+ \\
& +a_{3}^{(n)} L_{2}^{2} L_{1}+a_{4}^{(n)} L_{2}^{2} L_{3}+a_{5}^{(n)} L_{3}^{2} L_{1}+a_{6}^{(n)} L_{3}^{2} L_{2}+2 a_{7}^{(n)} L_{1} L_{2} L_{3},
\end{aligned}
$$

where are

$$
\begin{aligned}
& a_{1}^{(n)}=w_{1}^{(n)}-w_{2}^{(n)}-b_{3} \varphi_{1}^{(n)}-c_{3} \psi_{1}^{(n)} \\
& a_{2}^{(n)}=w_{1}^{(n)}-w_{3}^{(n)}+b_{2} \varphi_{1}^{(n)}-c_{2} \psi_{1}^{(n)} \\
& a_{3}^{(n)}=w_{2}^{(n)}-w_{1}^{(n)}+b_{3} \varphi_{2}^{(n)}+c_{3} \psi_{2}^{(n)} \\
& a_{4}^{(n)}=w_{21}^{(n)}-w_{3}^{(n)}-b_{1} \varphi_{2}^{(n)}-c_{1} \psi_{2}^{(n)} \\
& a_{5}^{(n)}=w_{3}^{(n)}-w_{1}^{(n)}-b_{2} \varphi_{3}^{(n)}-c_{2} \psi_{3}^{(n)} \\
& a_{6}^{(n)}=w_{3}^{(n)}-w_{2}^{(n)}+b_{1} \varphi_{3}^{(n)}+c_{1} \psi_{3}^{(n)} \\
& a_{7}^{(n)}=\frac{1}{4} \sum_{s=1}^{6} a_{s}^{(n)} .
\end{aligned}
$$

Here $L_{i}, i=1,2,3-L$ - are the coordinates, determined by the ratio [3]:

$$
L_{i}=\frac{1}{2 \Delta}\left(a_{i}+b_{i} x+c_{i} y\right),
$$


where is

$$
a_{1}=x_{2} y_{3}-y_{2} x_{3} ; \quad b_{1}=y_{2}-y_{3} ; \quad c_{1}=x_{3}-x_{2} .
$$

Displacements of the middle surface of the base of layers and the filler are a linear polynomial

$$
\begin{gathered}
u_{0 h}^{(n)}=u_{1}^{(n)} L_{1}+u_{2}^{(n)} L_{2}+u_{2}^{(n)} L_{2} ; \\
v_{0 h}^{(n)}=v_{1}^{(n)} L_{1}+v_{2}^{(n)} L_{2}+v_{2}^{(n)} L_{2} . \\
w_{h}^{(3)}=w_{1} L_{1}+w_{2} L_{2}+w_{3} L_{3} .
\end{gathered}
$$

Than the total potential energy of each triangle can be written in the local coordinate system in the form of:

$$
\begin{gathered}
\hat{\jmath}\left(\hat{v}_{h}\right)=\sum_{n=1}^{3} \hat{U}_{h}^{(n)}-\sum_{n=1}^{2} \sum_{i=1}^{3}\left(F_{x i}^{(n)} \hat{u}_{i}^{(n)}+F_{y i}^{(n)} \hat{v}_{i}^{(n)}+F_{z i}^{(n)} \hat{w}_{i}^{(n)}+F_{\varphi i}^{(n)} \hat{\varphi}_{i}^{(n)}+F_{\psi i}^{(n)} \hat{\psi}_{i}^{(n)}\right) \\
\ni\left(v_{h}\right) \equiv \ni(\vec{v})=\frac{1}{2}(K \vec{v}, v)-(\vec{f}, \vec{v}) ; \vec{v}, \vec{f} \in R,
\end{gathered}
$$

where $K$ - is a positive definite symmetric matrix of order $N$ and $\vec{f}$ - is a vector of a nodal external load with dimension $N$. Then the problem of determining the stress-strain state of the structures can be represented as the minimization of a quadratic functional

$$
\vec{u} \in R^{n} ; \ni(\vec{u})=\inf _{\vec{v} \in R^{N}} \ni(\vec{v}) .
$$

Minimization of the functional was provided by the method of coordinate descent [4] in which the vector of approximation is searched in the form

$$
\vec{v}^{k+1}=\vec{v}^{k}+\lambda_{i}^{k+i} \vec{e}_{i}, \quad i=1, \ldots, N,
$$

where $\vec{e}_{i}$ - is the unit vector in the direction $v_{i}^{k}, \lambda_{i}^{k+1}$ - is the step. After substituting (20) in functional $Э(\vec{v})$ and taking into account that $Э\left(\vec{v}^{k+1}\right)$ is a quadratic function, we are obtain:

$$
\ni\left(\overrightarrow{\mathrm{v}}^{k+1}\right)=Э\left(\overrightarrow{\mathrm{v}}^{k}\right)+\lambda_{i}^{k+1} \frac{\partial \ni}{\partial \mathrm{v}_{i}^{k}}+\frac{1}{2}\left(\lambda_{i}^{k+1}\right)^{2} \frac{\partial^{2} \ni}{\partial \mathrm{v}_{i}^{k^{2}}} .
$$

Then in the transition to " $\mathrm{k}+1$ "'-st the functional approximation gets increase

$$
\Delta Э=\lambda_{i}^{k+1} \sum_{m=1}^{M} \frac{\partial Э_{m}}{\partial v_{i}^{k}}+\frac{1}{2}\left(\lambda_{i}^{k+1}\right)^{2} \sum_{m=1}^{M} \frac{\partial^{2} Э_{m}}{\partial v_{i}^{k^{2}}} .
$$

From a physical point of view $\Delta \ni$ is a change of potential energy subdomains that are surround the $\mathrm{j}$ node in which the component $v_{i}^{k}$ gets the increase $\lambda_{i}^{k+1} \vec{v}^{k}$ at the last regular displacements. 
The magnitude $\lambda_{i}^{k+1}$ is determined from the conditions of maximum of functional decrease

$$
\frac{\partial \Delta \ni}{\partial \lambda_{i}^{k+1}}=0
$$

Then step is defined as follows:

$$
\lambda_{i}^{k+1}=-\frac{\sum_{m=1}^{M} \frac{\partial \ni_{m}}{\partial v_{i}^{k}}}{\sum_{m=1}^{M} \frac{\partial^{2} \ni_{m}}{\partial v_{i}^{k^{2}}}}
$$

To evaluate the effectiveness of this method, it was solved to test a large number of tasks. Some of them are shown in the tables 1,2

Table 1.

The maximum deflection of a three-layered square plate.

Comparison the coordinate-wise descent method (MCD) with experimental data: $a=0,56 \mathrm{~m} ; h_{1}=h_{2}=0,8^{*} 10^{-3} \mathrm{~m}$; for D16-T: $E_{1}=E_{2}=7 * 10^{4} \mathrm{MPa}$; $v_{l}=v_{2}=0,33$; for PCV-1: $h_{3}=1,9 * 10^{-2} \mathrm{~m} G_{x z}=G_{y z}=41,06 \mathrm{MPa}, q=20,3 \mathrm{KPa}$.

\begin{tabular}{|l|l|l|l|l|l|}
\hline $\begin{array}{c}\text { Number of } \\
\text { triangles }\end{array}$ & $\begin{array}{c}w_{\text {H.s }} * 10^{3} \\
(\mathrm{~m})\end{array}$ & $\Delta_{1} \%$ & $\begin{array}{c}\mathrm{W}_{\mathrm{s}}^{*} 10^{3} \\
(\mathrm{~m})\end{array}$ & $\Delta_{1} \%$ & $\begin{array}{c}\mathrm{W}_{\mathrm{e}} * 10^{3} \\
(\mathrm{~m}),[1]\end{array}$ \\
\hline $40 \times 40$ & 0,8866 & 10,6 & 0,9012 & 9,3 & \\
\cline { 1 - 4 } $60 \times 60$ & 0,9051 & 8,8 & 0,9191 & 7,4 & \multirow{2}{*}{0,993} \\
\cline { 1 - 4 } $80 \times 80$ & 0,9172 & 7,6 & 0,9302 & 6,3 & \\
\cline { 1 - 4 } $100 \times 100$ & 0,9218 & 7,2 & 0,9358 & 5,8 & \\
\hline $150 \times 150$ & 0,9269 & 6,7 & 0,9389 & 5,6 & \\
\hline
\end{tabular}

Table 2.

The values of the maximum deflection of a three-layer shallow shell

\begin{tabular}{|c|c|c|l|l|l|}
\hline \multirow{2}{*}{$\mathrm{b}(\mathrm{m})$} & $\mathrm{R}(\mathrm{m})$ & \multirow{2}{*}{$\begin{array}{c}\text { number of } \\
\text { elements }\end{array}$} & \multicolumn{2}{|c|}{$\mathrm{W}_{\max } * 10^{5}(\mathrm{~m})$} & \multirow{2}{*}{$\Delta_{1} \%$} \\
\cline { 3 - 4 } & & $\mathrm{MCD}$ & $\mathrm{MFE}[5]$ & \\
\hline \multirow{3}{*}{0,539} & \multirow{3}{*}{0,561} & $60 \times 60$ & 7,548 & & 6,3 \\
\cline { 3 - 4 } & & $80 \times 80$ & 7,426 & \multirow{2}{*}{7,1} & 4,6 \\
\cline { 3 - 4 } & & $100 \times 100$ & 7,328 & & 3,2 \\
\hline \multirow{3}{*}{0,509} & \multirow{3}{*}{0,373} & $60 \times 60$ & 3,535 & \multirow{3}{*}{3,3} & 7,1 \\
\hline & & $80 \times 80$ & 3,466 & 5,2 \\
\hline & & $100 \times 100$ & 3,429 & & 3,9 \\
\hline
\end{tabular}




\section{Conclusions}

An efficient and economical method of calculating the layered shell structure with a filler was proposed in this work. As opposed to the normal straight line hypothesis, the nonlinear function was used for the displacement of the filler. The procedure was based on the variational-grid approach of formation the functional with further minimization it's by the method of coordinate-wise descent. This approach avoids the well-known difficulties associated with the formation, storage and operation with the global stiffness matrices and allows to solve tasks of large dimension with using only the PC random access memory.

\section{References}

1. Алфутов Н. А. Расчет многослойных пластин и оболочек из композиционных материалов / Н. А. Алфутов, П. А. Зиновьев, Б. Г. Попов// М.: Машиностроение, 1984.-264 с.

2. Василенко Н. В. Расчет трехслойных пластин с мягким заполнителем, подверженных статическим и динамическим нагрузкам / Н. В. Василенко, А. Е. Бабенко, С. И. Трубачев / К.: ИПП, Проблемы прочности. 1989.-№2.-С. 71-74.

3. Зенкевич О. Метод конечных элементов в технике / О. Зенкевич М.: Мир.-1975.-541 с.

4. Бабенко A. $C$. Застосування і розвиток метода по координатного спуску в задачах визначення напружено-деформованого стану при статичних та вібраційних навантаженнях / А. С. Бабенко// К: КПИ, 1996.-96 с.

5. Пискунов В. Г. Линейные и нелинейные задачи расчета слоистых конструкций / В. Г. Пискунов, В. Е. Вериженко// К.: Будівельник, 1986.$176 \mathrm{c}$. 